\title{
Lohkotietopankki kokoaa kasvintuotannon viljelytietoa, tuottaa seuranta- tuloksia ja toimii jäljitettävyydessä
}

\author{
Sari Peltonen ja Pertti Savela \\ ProAgria Maaseutukeskusten Liitto, PL 251,01301Vantaa, etunimi.sukunimi@proagria.fi
}

Kasvintuotannon tulosten seurantaan, arviointiin ja vertailuun on kehitetty työväline, joka pohjautuu lohkomuistiinpanojen tarkkaan hyödyntämiseen. Lohkotietopankki on ProAgria Maaseutukeskusten Liiton kehittämä tietojärjestelmä, jonne kootaan kasvintuotannon viljelytekniikka- ja satotietoja käytännön viljelyksiltä. Tietopankin tietosisältö koostuu lohkokohtais ista viljelytiedoista, tuotantopanosten käyttötiedoista ja -ajankohdista, sadon määrä- ja laatutiedoista sekä taloudellisista laskelmista. Lohkotietopankin päätavoitteena on tuottaa tietoa kasvintuotannon kehittämiseen. Lohkoittain kirjatut viljelytoimenpiteet ja niiden tuloksena saavutettu sato ja laatu tuottavat tietoa siihen, millaisella viljelytekniikalla ja millaisella tuotantopanosten käytöllä parhaimpaan, niin määrälliseen, laadulliseen kuin taloudelliseen tulokseen päästään.

Lohkotietopankin kehitystyö on aloitettu vuonna 2000. Tällä hetkellä aineistoa on eri vuosilta yhteensä noin 183000 ha:n alalta, ja tiloja mukana järjestelmässä on 900. Mitä enemmän ja useammilta vuosilta aineistoa tietopankkiin saadaan, sitä paremmiksi muodostuvat tulosten tarkastelu- ja vertailumahdollisuudet.

Lohkotietopankin käyttöliittymän avulla aineistot voidaan jaotella tulosten perusteella neljä nneksiin heikoimmasta parhaimpaan, jolloin voidaan tehdä vertailua siitä, mihin luokkaan omat tulokset yltävät, ja analysoida, mitä kannattaa tehdä tulosten parantamiseksi. Tietojärjestelmä antaa mahdollisuuden tilan tulosten vertailuun, esimerkiksi muiden saman alueen, samalla maalajilla tai samaa viljelykasvia viljelevien tilojen välillä. Tietoaineisto on suojattu niin, että yksittäisen tilan tietoja ei ole ulkopuolisen henkilön mahdollista nähdä. Järjestelmä ei myöskään näytä sellaista luokiteltua tietoa, jossa on alle viiden tilan tiedot mukana

Lohkotietopankki toimii työvälineenä ProAgria Maaseutukeskusten ProViljelys -kasvintuotannon kehittämispalvelussa. Palvelussa selvitetään yhtenä osana satokauden päätyttyä kasvintuotannon viljelytekninen onnistuminen ja taloudellinen tulos sekä määritetään kehittämiskohteet ja tavoitteet seuraavalle vuodelle. Lohkotietopankki toimii tässä palvelussa tilakohtaisen tiedon sekä vertailutiedon tuottajana.

Lohkotietopankki tarjoaa myös välineen ajantasaisen viljelytiedon seuraamiseen. Vuosittaiset lajikekohtaiset viljelytulokset, tuotantopanosten käytön kannattavuudet ja muokkausmenetelmien erot ovat esimerkkejä Lohkotietopankin tietojen käsittelymahdollisuuksista.

Lohkotietopankki mahdollistaa myös ruuan alkuperän ja suomalaisen tuotantotavan osoittamisen sekä jäljitettävyyden. Jäljitettävyyden perustana toimivat lohkokohtaiset viljelymuistiinpanot sekä satotiedot kirjattuna varastoihin ja edelleen myyntieriin. Tuotettuun raaka-aine-erään liitetty myyntierätunnus on jäljitettävissä aina elintarvikeketjun seuraavalle portaalle, jonka toimija vastaa oman kirjanpitonsa avulla edelleen jäljitettävyyden säilymisestä. Riskienhallintatapauksissa järjestelmän avulla päästään tarkistamaan tuotantoon liittyviä tietoja. Lohkotietopankin avulla jäljitettävyys on mahdollista ulottaa yksittäiselle peltolohkolle asti ja siellä tehtyihin yksittäisiin viljelytoimenpiteisiin saakka.

Asiasanat: lohkokohtaiset muistiinpanot, tulosten seuranta, vertailutiedot, viljelytekniikka, talous, jäljitettävyys, lohkotietopankki 


\section{Johdanto}

Tilan johtamisessa keskeisiä ovat päämäärien ja tavoitteiden selkeyttäminen sekä tulosten seuranta. Menestyvä yritys asettaa tavoitteita, seuraa niiden tote utumista ja saavutettuja tuloksia sekä arvioi, korjaa ja parantaa toimintatapoja, jotta haluttuihin tavoitteisiin ja tuloksiin päästään. Ammattimainen kasvintuotanto edellyttää tavoitteellista suunnittelua, tuotannon prosessien hallintaa, tietoa tuotannon nykytilasta, tuloksista ja kehittämiskohteista sekä markkinoinnin osaamista. Lisäksi tilan resurssie n tulee olla sopivassa mittakaavassa tuotannon laajuuteen nähden, jotta yrittäjän oma hyvinvointi ja jaksaminen ovat kestävällä pohjalla.

Huolellinen suunnittelu sekä tulosten mittaaminen ja arviointi johtavat pitkällä tähtäimellä parempaan tuotannon riskien hallintaan. Aktiivisella tulosten seurannalla selviävät mm. millainen on peltolohkojen satopotentiaali, mitä lajikkeita kannattaa viljellä milläkin peltolohkolla ja millaista tuotantopanosten käyttöä ne vaativat sekä millainen on onnistunut kylvömuokkausmenetelmä. Tuotannon taloudellisen kannattavuuden laskenta paljastaa viime kädessä sen, mihin viljelykasveihin ja millä viljelytekniikalla kannattaa tilalla jatkossa panostaa.

Hyväkään yritys ei menesty keskittämällä tavoitteiden asettamisen ja toiminnan mittaamisen yksipuolisesti vain yrityskokonaisuuden tiettyyn osa-alueeseen, esim. tuotannon prosessien kuten viljelytekniikan kehittämiseen. Tarkastelemalla yritystä kokonaisuutena ja huomioimalla taloudellinen tulos, asiakastyytyväisyys, sisäinen tehokkuus, osaamisen ja hyvinvoinnin kehittyminen sekä ympäristö päästään yrityksen kehittämisessä tehokkaammin haluttuun suuntaan. Tasapainoisen tulosajattelun periaate varmistaa, ettei tilan johtaminen ole liian yksipuolista ja ettei yrityskokonaisuuden tiettyä osaaluetta kehitetä huomioimatta, mitä samaan aikaan tapahtuu muilla alueilla (Jokipii \& Teräväinen, 2000).

Tavoitteiden asettaminen konkretisoi yrityksen päämäärät. Yrityksen tulee tietää mitä tuotetaan, kenelle tuotetaan, millä kustannuksilla ja mitkä ovat tuotteen asiakasvaatimukset. Tavoitteiden asettaminen määräytyy sen pohjalta, mitkä ovat omat tulokset nyt ja mihin halutta isiin päästä. Viljelyn tulosten vuosittainen tarkastelu ja arviointi ovat välttämättömiä, kun lähdetään miettimään uusia suunnitelmia, tavoitteita ja erityisesti menetelmiä, miten asetettuihin tavoitteisiin päästään. Menestyvät tilat eivät kuitenkaan tyydy pelkästään tarkastelemaan omia tuloksia. Kun omia tuloksia verrataan muihin tiloihin ja etenkin parhaisiin, saadaan tuotannon kehittämisen tarkasteluun arvokasta lisätietoa. Lohkotietopankki on väline, joka tarjoaa vertailutietoa toiminnan kehittämiseen (Peltonen ym. 2005).

Lohkotietopankin tiedonkeruun perusajatus on kerran tallennettujen tietojen (esim. ympäristötuen edellytyksenä) hyödyntäminen tilan kehittämiseen. Jotta tiedon keruu Lohkotietopankkiin ei tuottaisi ylimääräistä työtä, on tavoitteena ollut, että viljelymuistiinpanot tallennetaan vain yhteen kertaan. Kerran tallennettuna tietokoneelle, tiedot ovat samalla lähetettävissä Lohkotietopankkiin. Lisäksi tietojen tarkastelu tapahtuu reaaliaikaisesti käyttöjärjestelmän kautta Internetissä.

Tilan pääsevät mukaan Lohkotietopankkijärjestelmään ottamalla yhteyttä paikallisen ProAgria Maaseutukeskuksen kasvintuotantoneuvojaan. Parhaimman hyödyn tietojen käytöstä saa, kun liittyy ProAgria Maaseutukeskusten perustamiin viljelyn kehittämisryhmiin (ProViljelys -tilaryhmät), jotka saavat etuutena pääsyn tietojärjestelmään. ProViljelys -ryhmissä toimintaa ohjaa neuvoja, joka on apuna tiedon kokoamisessa tietopankkiin ja ennen kaikkea tilan tulosten analysoinnissa.

\section{Lohkotietopankin tietoaineiston koostumus}

Lohkotietopankin tietosisältö koostuu kasvulohkokohtaisista viljelyn muistiinpanoista käytännön viljelyksiltä:

- peltolohkon vilja vuustiedot ( $\mathrm{pH}$, ravinteet)

- muokkaus ja hoitotyöt (päivämäärä ja muokkaustapa)

- kylvötiedot (siemen, määrä $\mathrm{kg} / \mathrm{ha}, \mathrm{kpl} / \mathrm{m}^{2}$, päivämäärä ja tapa)

- lannoitus ja maanparannus (valmisteet, määrä kg/ha, päivämäärä)

- kasvustohavainnot (rikat, taudit jne.)

- kasvinsuojelutoimenpiteet (valmisteet, määrä kg, g, 1/ha, päivämäärä)

- sadon määrä $(\mathrm{kg}$, ry/ha) ja laatu

Talouslaskelmat sisältävät joko lohko-, lajike- tai kasvikohta isesti lasketun taloustuloksen. Tulos on laskettu nettovoittoon saakka sisältäen tuotot (sato ja tuet), muuttuvat kustannukset, työkustannukset, yleis-, kone- ja rakennuskustannukset sekä pellon kustannukset: 
- sadosta saatu myyntihinta (€/kg, tn)

- kasvintuotannon tuet (€/ha)

- tuotantopanosten eli siementen, lannoituksen ja kasvinsuojelun kustannukset (€/ha)

- työkirjanpito (h/ha)

- koneiden ja rakennusten käyttö-, ylläpito- ja pääomakustannukset (€/ha)

- yleiskustannus (€/ha)

- pellon ja ojituksen kustannus (€/ha)

Lohkotietopankkiin on kerätty kasvintuotannon lohkomuistiinpanoaineistoa vuodesta 2000 lähtien, ensin pilottitilojen kautta, nyt osana ProViljelys- viljelyn kehittämispalvelua. Lohkotietopankissa on lohkokohtaista viljelytietoa keskimäärin 60000 ha:Ita ja 900 tilalta vuosittain. Tämä vastaa n. $2 \%$ koko maan viljelypinta-alasta ja tilojen määrästä. Keskimääräinen tilakoko aineistossa on n. 70 ha. Kumulatiivisesti yli vuosien 2000-04 tarkasteltuna aineistoa on yhteensä 183000 ha. Talouslaskelmaaineistoja on vastaavasti n. 90000 ha:Ita ja 1400 tilalta vuosittain ja kumulatiivinen kertymä on 238000 ha. Luonnonmukaisen tuotannon osuus aineistosta on parina viime vuonna ollut noin $5 \%$, mikä vastaa myös niiden todellista osuutta. Pääosa Lohkotietopankin aineistoista on Etelä-Suomesta. Aineistot ovat sijainnista johtuen olleet varsin viljapainotteisia. Kevätvehnästä, mallasohrasta sekä rehuohrasta ja -kaurasta on eniten tietoja (60-70 \% aineistosta). Viimeisimmän vuoden aikana voimakas viljapainotteisuus on tasapainottunut Keski- ja Pohjois-Suomen nurmivaltaisilla aineistoilla. Maalajijakauma on maantieteellisestä sijainnista johtuen varsin kivennäismaavaltainen.

Tietojen toimittaminen Lohkotietopankkiin tapahtuu neuvojien tekemän tarkistusten kautta, jolla varmistetaan tietojen oikeellisuus ja luotettavuus. Tietojen lähettämiseen Lohkotietopankkiin tarvitaan myös aina tilan lupa. Lohkotietopankki toimii käyttäjätunnusten kautta. Lohkotietopankin tarjoamia tulosten vertailumahdollisuuksia tilat pääsevät hyödyntämään toimittamalla oman tilan tiedot järjestelmään. Lohkotietopankkiin tietojen lähettäminen edellyttää, että lohkokohtaiset muistiinpanot on kirjattu jollakin ATK-pohjaisella viljelysuunnitteluohjelmistolla. Tällä hetkellä suorin pääsy tietojen lähettämiseen on Wisu - viljelysuunnitteluohjelman avulla. Lohkotietopankin tietojen käsittely tapahtuu valmiiksi rakennetun käyttöjärjestelmän kautta tai suoraan SQL-tietokannasta.

\section{Lohkotietopankin hyödyntämismahdollisuudet}

Lohkotietopankki antaa mahdollisuuden tilan tulosten vuosittaiseen seurantaan sekä vertailuun muihin saman alueen, samalla maalajilla, samaa viljelykasvia tai jopa lajiketta viljelevien tilojen välillä. Erityistä kehittämistietoa saadaan jakamalla aineisto esimerkiksi sato- tai laatutulosten perusteella neljä nneksiin heikoimmasta parhaimpaan. Tällöin voidaan tehdä vertailua siitä, mihin luokkaan omat tulokset yltävät ja analysoida, mitä kannattaa tehdä tulosten parantamiseksi.

Lohkotietopankki on yksi keskeisimmistä työvälinesitä ProViljelys -palvelussa, jossa sen avulla on mahdollista arvioida ja seurata omia tuloksia vertailutietoja vasten, havainnollistaa tilan kehityskohteet sekä tarkastella parhaisiin tuloksiin johtaneita viljelykäytäntöjä.

Lohkotietopankin vertailutietojen avulla voidaan seurata yleisellä tasolla kasvintuotannon viljelykäytäntöjä, saavutettuja satoja ja ravinteiden käytön hyötysuhteita sekä kannattavuustuloksia vuosittaisella tarkkuudella tai aikasarjoin, jolloin nähdään tuotannon kehityssuuntia.

Lohkotietopankki palvelee myös yhä enemmän aineistojen karttuessa viljelykasvien lajiketiedon tuottajana. Tiedon vahvuutena on sen yhteys käytännön olosuhteisiin. Tällöin tietoa voidaan hyödyntää merkittävässä määrin viljelyn suunnittelussa, kun halutaan tietää, miten tietty lajike menestyy tietyillä alueilla tai maalajeilla, ja minkälaisten tuotantopanosten käytöllä lajikkeen paras sadontuottokyky saadaan esille.

Lohkotietopankki mahdollistaa myös alkuperän ja suomalaisen tuotantotavan osoittamisen sekä antaa tie toa suomalaisen kasvintuotannon kilpailukyvystä ja kannattavuudesta.

Lohkotietopankista voidaan erilaisia hakutermejä käyttämällä hakea viljelyn tuotantotapaan liittyviä yksityiskohtia. Tämä ominaisuus palvelee riskienhallinnassa ja jäljitettävyydessä. Mahdollisissa ongelmatilanteissa voidaan tarkistaa haluttu tieto, esim. tuotantopanosten käyttö vastaanotettujen satoerien lohkomuistiinpanoista myyntierätunnusta käyttämällä. Tämä mahdollistaa myös satoerien pysäyttämisen vastaanottoketjussa lisäanalyysejä varten. Tällainen tilanne voi olla esim. tietyn kasvinsuojeluaineen jäämäriski, jolloin analyysit voidaan kohdentaa vain niihin ennakkonäytte isiin, joiden tuotannossa ko. kasvinsuojeluainetta on käytetty. 
Esimerkkejä jäljitettävyyteen ja riskienhallintaan liittyvistä selvityksistä:

? käytetty viljelytekniikka

? tuotantopanosten käyttömäärät $(\mathrm{kg} / \mathrm{ha})$

? puhdistamolietteen käyttö

? ravinteiden käytön tehokkuus (ravinnetaseet)

? sadon laatu- ja haitta-aineanalyysitiedot

? kasvinsuojeluaineiden tehoainemäärät / ha

? kasvinsuojeluvalmisteiden käyttö aineen tarkkuudella (on/ei)

? pienannosaineiden käyttömäärät suhteessa hormonivalmisteiden käyttömääriin

? glyfosaatin käyttömäärät ja -ajankohdat

Jäljitettävyyden perusajatus on, että elintarvikkeeseen tai sen raaka-aineeseen liittyvä tärkeä todennettavaksi katsottu ominaisuus pystytään selvittämään tuotteen jalostusketjussa riippumatta siitä, mihin vaiheeseen ketjua tuo ominaisuus liittyy. Jalostusketjussa tämä edellyttää, että raaka-aine-erää seuraa aina tunniste, jolla erä on halutulla tarkkuudella tunnistettavissa jokaisessa jalostusketjun vaiheessa. Elintarvikkeen raaka-aineen syntypaikalla, maatilalla tämä tarkoittaa kasvintuotannon osalta, että jokaisesta korjattavasta satoerästä tallennetaan Lohkotietopankkiin kasvupaikan tunniste, käytännössä kasvulohkon tunnus, joka yksilöi kyseiseen erään liittyvät viljelytapahtumat.

Käytännössä kasvulohkotasoinen elintarvikkeen raaka-aineen jäljitettävyys on suurin tarkkuus, johon voidaan päästä. Jo maatilan varastossa eri kasvulohkoilta korjattu sato voi yhdistyä, jolloin jäljitettävyyden kannalta tullaan tilanteeseen, jossa pystytään todentamaan luettelomaisesti, mitä viljelytietoja on erän taustalla ja laskemaan esimerkiksi keskiarvoja lannoitteiden käytöstä kyseisen satoerän tuottamisessa. Jalostusketjun lopputuotteelle asettamien laatutavoitteiden saavuttaminen edellyttää, että raaka-aineen syntypaikalla maatilalla on tiedossa minkälaista laatua ostaja tavoittelee, ja miten tietyn laatuiset erät pystytään pitämään erillään maatilan varastossa (esim. lastenruokaraakaaineet).

Jäljitettävyyteen vaatimassa tietojen siirrossa tulee maatilalta lähtevään raaka-aine-erään liittää myyntierän tunniste, jona toimii esimerkiksi kaupan tai teollisuuden vastaanottotodisteen numero. Tällä tunnuksella erä on edelleen jäljitettävissä ostajan vastaanottopisteessä ja varastossa. Vastaanottajan ja siitä eteenpäin olevan jalostusketjun tietojärjestelmissä on mainittua tunnistetta tai sen johdannaisia kuljetettava mukana sillä tarkkuudella, kun jäljitettävyyttä halutaan toteuttaa. Parhaimmillaan mistä tahansa lopputuotteesta tai suuresta raaka-aine-erästä pystytään selvittämään viljelyn tuotantotapatietoja ja tuotantopanosten käyttömääriä.

Jäljitettävyyteen liittyvä takaisinkysely tapahtuu vaiheittain. Jos raaka-aine-erän loppukäyttäjä, esim. teollisuus haluaa selville erän tuotantotapatietoja, kysely tehdään edelliselle portaalle, joka voi olla esim. kaupan keskusvarasto. Tämän jälkeen kauppa pystyy selvittämään kirjanpitonsa perusteella tiloilta vastaanottamansa satoerät käyttäen hyväksi vastaanottotodisteen numeroita. Näiden tunnisteiden perusteella Lohkotietopankissa päästään käsittelemään ko. tilojen tuottamien satoerien lohkokohtaisia muistiinpanoja. Jäljitettävyyden edellyttämät haut tietokannasta toteutetaan selainpohjais ina. Hakujen tekeminen edellyttää tiedon käyttöoikeuksista sopimista ja käyttäjän vahvaa tunnistusta.

\section{Lohkotietopankin käytännön viljelytuloksia}

Lohkotietopankin tulokset ovat havainnollistaneet, että eri peltolohkoilla satotasojen välillä voi olla jopa $3000 \mathrm{~kg} / \mathrm{ha}$ ero, vaikka esimerkiksi lannoitustaso on samanlainen. Tällaisessa tapauksessa on erityisen tärkeää selvittää, mikä rajoittaa sadontuottoa lohkolla ja sen perusteella arvioida lohkon satopotentiaali, lannoitustaso ja muu tuotantopanosten käyttö uudelleen. Alhaisen, alle $3000 \mathrm{~kg} / \mathrm{ha}$ satotason lohkoilla typen käyttömäärää tulisi selvästi alentaa ja kasvitautien torjuntakäsittelyitä harkita tarkoin sadon käyttötarkoitus huomioiden.

Lohkotietopankin vuosien 2002-04 yhteenvetotuloksissa syys- ja kevätvehnällä sekä ohralla saatiin parhain satovaste $(670-930 \mathrm{~kg} / \mathrm{ha})$ tautitorjunnalle, mutta esimerkiksi vähemmän kasvinsuojeluun panostetulla kaurallakin tautitorjunta antoi lähes $500 \mathrm{~kg} / \mathrm{ha}$ sadonlisän. Ruis hyötyi tautitorjunnasta vähiten sadonlisän ollessa $150 \mathrm{~kg} / \mathrm{ha}$. Viime vuoden 2004 tuloksissa tautitorjunta lisäsi viljoilla satoa keskimäärin $810 \mathrm{~kg} / \mathrm{ha}$, mutta kuivanakin vuonna 2002 oli tautitorjunnalla saatu sadonlisä varsin 
merkittävä eli $435 \mathrm{~kg} / \mathrm{ha}$. Tautien torjuntakäsittelyt antoivat kevätvehnällä keskimäärin $140 \mathrm{~kg} / \mathrm{ha}$ sadonlisän alle $3 \mathrm{tn} / \mathrm{ha} \mathrm{satotasoilla,} \mathrm{kun} \mathrm{yli} 4 \mathrm{tn} / \mathrm{ha}$ satotasoilla sadonlisä oli lähes $400 \mathrm{~kg} / \mathrm{ha}$. Ohralla sitä vastoin päästiin jo alle $3 \mathrm{tn} / \mathrm{ha}$ satotasoilla $250 \mathrm{~kg} / \mathrm{ha}$ sadonlisiin.

Korkea satotaso oli yhteydessä parhaaseen aloudelliseen tulokseen viljoilla. Korkeilla satotasoilla myös tuotantopanosten käytöstä saatiin parhain satovaste. Vaikka korkeilla satotasoilla esimerkiksi kasvinsuojeluun panostettiin selkeästi enemmän kuin alhaisemmilla satotasoilla, tuotantokustannukset sekä hehtaaria että tuotettua satokiloa kohti olivat niillä selvästi alhaisemmat.

Parhaaseen satoon ja taloudellisen tulokseen pääsemiseksi ei ole osoitettavissa yhtä selittävää tekijä. Peltolohkon hyvä $\mathrm{pH}$ on ollut eri viljelyn taustatekijöistä selkeimmin ja säännönmukaisimmin yhteydessä parhaimpiin satotasoihin. Parhaimmilla lohkoilla yhdellä typpikilolla tuotettiin $54 \mathrm{~kg}$ satoa kun se heikommilla lohkoilla jäi $27 \mathrm{~kg}$ :aan. Kasvinsuojelu, erityisesti tautitorjunta oli selkeästi yhteydessä parhaimpiin satotuloksiin. Parhaimman taloudellisen tuloksen tehneillä konekustannukset olivat selvästi muita alhaisemmat. Paras tulos näyttää selittyvän tilan kokonaisvaltaisella hyvällä johtamisella, jossa satopotentiaalia rajoittavat tekijät on minimoitu ja tuotannon kustannukset on saatu hallintaan.

Kun viljan keskimääräinen tuotantokustannus oli 27 snt/kg vuosina 2003-04, päästiin parhaimmilla lohkoilla alle 20 sentin tuotantokustannuksiin tuotettua satokiloa kohti. Tulos osoittaa, että viljan tuotanto on Suomessa vahvasti riippuvaista tuista eikä parhaimmillakaan tiloilla, jotka ovat optimoineet tuotantonsa ja kustannuksensa, pystytä tuottamaan viljaa nykyisillä markkinahinnoilla. Suomalaisen viljantuotannon kilpailukyvyn parantamisessa satotasojen nosto ja toisaalta tuotantokustannusten alentaminen ovat haasteellisia kehityskohteita. Pellon peruskunnon parantamisella ja tarpeenmukaisella kasvinsuojelulla voidaan merkittävästi vaikuttaa satotasojen nostamiseen, kun taas konekustannusten alentaminen vaikuttaa huomattavasti tuotantokustannusten hallintaan.

Suorakylvön odotetaan laskevan satotasoa muutamalla sadalla kilolla hehtaaria kohden ensimmäisten ns. siirtymävuosien aikana. Lohkotietopankin vuosien 2002-04 tulosten mukaan suorakylvö alensi erityisen voimakkaasti syys- ja kevätvehnän satoa $(270-580 \mathrm{~kg} / \mathrm{ha})$, mutta toisaalta lisäsi kauran ja rukiin satoa n. $160 \mathrm{~kg} / \mathrm{ha}$. Ohralla suorakylvö antoi keskimäärin n. $120 \mathrm{~kg} / \mathrm{ha}$ alha isemman sadon kuin tavanomaisessa muokkaustekniikassa. Suorakylvön osuus aineistosta oli n. $5 \%$.

Viljojen satokehitys oli Lohkotietopankin viljelyaineistojen mukaan noususuunnassa mallasohralla ja kevätvehnällä. Sen sijaan kauran ja ohran satotasot olivat laskussa. Tuotantopanosten käytössä eri viljoilla ei ole tapahtunut suuria muutoksia viimeisen viiden vuoden aikana. Ainoastaan typen käyttö vaihtelee, mutta fosforin ja kaliumin käyttö on ollut suhteellisen samalla tasolla. Kasvinsuojeluaineiden käytössä näkyy puolestaan selvästi tarpeenmukaisuus. Esimerkiksi tuholaistorjuntaa tehtiin suhteellisesti eniten vuonna 2002, jolloin mm. ennustettiin tuomikirvariskiä. Tautitorjunta oli taas yleisintä vuoden 2004 erityisen suosiollisissa oloissa taudinkehitykselle ja vuonna 2001, kun taas kuivina vuosina 2002-03 tautitorjuntaa tehtiin selvästi vähemmän.

\section{Johtopäätökset}

Tuotannon kannattavuuden parantaminen vaatii yrittäjiltä yhä enemmän huomion kiinnittämistä toimintansa tuloksiin ja niiden kehityssuuntiin. Tilat tarvitsevat tukea päätöksentekoon ja eri ratkaisuvaihtoehtojen etsimiseen. Omien tulosten seuranta ja vertailu korostuvat. Lohkotietopankki pyrkii osaltaan vastaamaan tähän haasteeseen. Myös yhä lisääntyvä kuluttajien tietoisuus ruuan alkuperästä lisää tarvetta kehittää valmiuksia elintarvikkeiden raaka-aineen jäljitettävyyteen. Tehokas jäljitettävyysketju vahvistaa myös suomalaisen raaka-aineen kilpailuetua markkinoilla. Sähköinen tiedonsiirtomalli Lohkotietopankin kautta mahdollistaa ostajalle raaka-aineen laatua koskevan riskien hallinnan, laadun kehittämisen sekä alkuperän ja suomalaisen tuotantotavan osoittamisen.

Kirjallisuus:

Jokipii, P \& Teräväinen, H. (toim.). Laatutyöllä tuloksiin. Tieto Tuottamaan n:o 89. Otavan Kirjapaino Oy, Keuruu. $96 \mathrm{~s}$.

Peltonen, S., Kiltilä, K., Räty, P., Kirkkari, A-M., \& Koivula, S. 2005. Suomalaisen viljaketjun kilpailukyky. Teoksessa: Palva, R., Kirkkari, A-M. \& Teräväinen, H. (toim.). Viljasadon käsittely ja käyttö. Tieto Tuottamaan n:o 108. Otavan Kirjapaino Oy, Keuruu. s. 4-19. 